\title{
Can Credit Unions Survive in Australia?
}

\author{
Kevin Davis
}

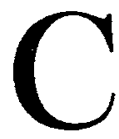

REDIT unions are specialist retail financial services firms offering loan and savings facilities, transactions services and financial advice. 'Specifically, they are cooperative financial institutions owned by their member/customers who satisfy some common bond criterion of belonging to a particular community, industrial or geographic group. Depositing members and borrowing members alike hold non-transferable shares (of nominal amount) in the cooperative, which entitle each member to one vote and an unspecified share of the accumulated net wealth of the cooperative in the event of its being wound up. The shares are redeemable at par to any member who leaves the cooperative, regardless of the accumulated net wealth of the cooperative.

Credit unions' activities and organisational form yield competitive advantages and disadvantages influencing their growth and penetration of the financial system. In the 50 years since credit unions were introduced to Australia, total assets of the sector have gradually increased to $\$ 15$ billion, and membership to $3.5 \mathrm{~m}$. However, in recent years the number of credit unions has declined significantly, from over 600 at the start of the 1980 s to 285 in late 1996 , as many smaller credit unions have found independent existence in the modern financial world too hard and merged with other credit unions. This raises the more general question of the likelihood of credit unions surviving in their present form in the current Australian environment. The Wallis Inquiry (1997) recommendations, if implemented, will partly determine the answer to this question, and a preliminary assessment of the impact of those recommendations on the future of credit unions is made in following sections.

\section{The Theory of the Credit Cooperative}

The stated objective of çredit unions is generally to maximise (in some sense) the welfare of their members. However, their cooperative structure creates a number of financial management problems. In cooperative institutions, owners are also customers, and there is no market in claims on the cooperative's accumulated net wealth. Profit generation and accumulation of net wealth involve the transfer of financial re-

\footnotetext{
${ }^{1}$ Descriptions of their activities can be found in Davis (1985) and Crapp and Skully (1985).

${ }^{2}$ Deshmukh et al. (1982) and Smith et al. (1981) are among the papers which focus upon credit union objectives.
}

Kevin Davis is Colonial Mutual Professor of Finance at the University of Melbourne. 
sources from private ownership to collective ownership. Financial management decisions of the cooperative involve transfers between members (as depositors, lenders, and users of services provided) and transfers between private and collective ownership. Consequently, management decisions can affect membership composition, as individuals likely to be net beneficiaries from cross subsidisation and wealth transfers are attracted to join and those who are potential net losers tend to leave. However, restrictions on eligibility for membership arising from the 'common bond' requirement limit, to some degree, the operation of such 'clientele' effects.

In analysing cooperative financial management, it is necessary to understand the determinants of individual member preferences between private ownership and collective ownership of financial resources. Trying to identify a collective objective function to guide management decisions runs into similar problems of interpersonal comparisons and aggregation to those identified by studies of social welfare functions. Various studies have attempted to examine empirically whether management decisions favour borrower or depositor members (Patin \& McNeil, 1991).

Further complications arise from the divorce between ownership and control and the consequent agency problems. On the one hand, the coincidence of owners and creditors (the depositor/members are the owners) eliminates the agency costs associated with debt and equity. With profit-oriented institutions, creditors/depositors are exposed to the possibility that owners will increase the riskiness of the institution's activities, since whereas the owners reap the entire benefits of favourable outcomes from risk-taking, creditors/depositors bear a significant part of the cost of unfavourable outcomes. This gives cooperatives a potential competitive advantage over profit-oriented institutions. 3 On the other hand, severe agency problems can arisc in credit unions from the divergent objectives of management and owners. The one-member-one-vote rule limits the ability of members of a cooperative to generate concentrations of voting power, thereby increasing managers' job security and their ability to award themselves excessive remuneration. Nevertheless, in practice, as Rasmusen (1988) points out, this may help explain the emergence of mutual and cooperative financial institutions. To the extent that managers of cooperatives are constrained in their ability to convert life-time above-normal remuneration into short-term gains, they have an incentive to

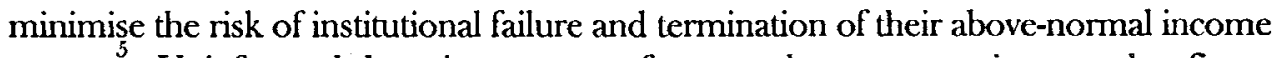
stream. Uninformed depositors may prefer mutuals or cooperatives to other finan-

\footnotetext{
${ }^{3}$ This potential advantage is, however, removed if other financial institutions, such as banks, can provide depositors with a guarantee of safety through deposit insurance schemes or (implicit or explicit) government guarantees, thereby removing the need for depositors to monitor the institution's activities. 4

Mayers and Smith (1986), in a study of life insurance companies converting from stock to mutual form, suggest an altemative explanation based on the efficiency gains from lower owner-creditor agency costs outweighing increased management-owner agency costs. 5

${ }^{5}$ This argument suggests that an important feature of prudential regulation of cooperative instiutions should be an emphasis upon limiting management's ability to undertake actions which involve short-term wealth transfers to itself. Provided that the rents are available to management only so long as the cooperative survives, management will have an incentive for risk-averse management.
} 
cial institutions, since the coincidence of owners and depositors and the incentives faced by management reduce the likelihood of risk-increasing activities.

Agency issues also arise from the credit union's role as a lender. Here, relatively tight common bonds which constrain the range of eligible borrowers can serve to reduce the problems of information asymmetry and thus the costs of monitoring borrowers, as well as reducing the $e x$ ante costs of assessing credit risk. These advantages may offset any cost disadvantages arising from cooperatives' small scale, although problems of risk concentration and liquidity fluctuations may become more important.

Kane and Hendershott (1994) note several features arising from the cooperative structure of credit unions which may create value in different ways from other financial institutions. They note that incentives for higher monitoring may be greater, for three reasons. First, volunteers and sponsors who contribute time and resources have incentives to monitor management, while common bonds may enhance information flows. Second, there has been greater bonding of credit union management and boards (reflecting the history of volunteer staff) by use of outside sureties than for other institutions, with providers of those sureties having strong incentives to monitor. Third, in the United States, the system of effective prepayment of deposit insurance premiums for credit unions provides incentives for individual credit unions to monitor other credit unions. Kane and Hendershott (1994) further note that common bond requirements limit the scope for managerial risktaking by: limiting the range of products to those suitable for the membership base; inhibiting rapid growth by restricting the deposit base; and constraining the ability of management to 'buy' business by distributing surplus to particular customers, since political pressures will emerge to protect the stakes of other members.

Credit unions also tend to be relatively transparent institutions. Providers of funds can determine relatively easily the nature of the assets held and the risks involved, since those assets are primarily loans to members of the common bond. This transparency and commitment to investment in assets which are liabilities of other members of the relevant community, upon whom social pressures may exist to honour obligations, may also provide credit unions with an advantage vis-à-vis more opaque institutions.

Other alleged sources of credit unions' competitive advantage include 'privileged' taxation treatment (since in many countries they have not been subject to company tax); access to free or subsidised services from sponsoring companies or community members; and a 'cost of funds' advantage which arises because members do not demand a rate of return on accumulated surpluses equivalent to that demanded by providers of equity capital to a joint stock company (though Miles, 1994, argues that, unless management is willing to reduce the insurance value of reserves to existing depositors, there is no such competitive advantage).

Will these alleged advantages enable cooperative financial institutions to compete successfully with other forms of financial institutions? 


\section{Taxation of Credit Unions}

Before 1995, credit unions in Australia were exempt from payment of company tax on profits (surplus) arising from business transacted with members. Since business with non-members comprised primarily the investment of liquid asset reserves in deposits and marketable securities, credit unions in effect paid no company tax. But since 1995, credit unions have become subject to company tax on their entire surplus (except those with a surplus below $\$ 50,000$ a year), with a view to subjecting credit unions to the same tax treatment as other depository institutions. However, under the imputation tax system that has applied in Australia since 1987, company tax paid is, in essence, a prepayment of shareholder-level tax, provided that after-tax profits are paid out as dividends. (Such dividends are known as 'franked' dividends and carry tax credits which can be used by the shareholder to offset other tax liabilities.) The problem for credit unions is that they have no mechanism available to pay franked dividends. Unlike US credit unions, whose at-call funds are essentially share capital on which an $c x$ post 'dividend' is declared at year's end, all funds raised by Australian credit unions (except for a nominal share amount from each member) take the form of deposits. Credit unions can distribute excess profits to members but only in the form of rebates of loan interest, which would not carry franking credits.

The impact of this can be seen with the aid of a simple example. Consider two institutions with identical balance sheets and interest rates; one is a cooperative and the other a joint stock company. For each, assets (A) of $\$ 100$ are funded by deposits (D) of $\$ 90$ and equity (accumulated surplus, $E$ ) of $\$ 10$. If assets earn a return $\left(\mathrm{r}_{2}\right)$ of 12 per cent a year and the cost of deposits $(\mathrm{rd})$ is 6 per cent a year, interest income is $\$ 100$ x $0.12=\$ 12$, interest expense is $\$ 90 \times 0.06=\$ 5.40$, and (assuming for simplicity's sake that operating costs and so forth are zero) profits before company tax are thus $\$ 6.60$. At a company tax rate $\left(\mathrm{t}_{\mathrm{c}}\right)$ of 36 per cent, company tax payments are $\$ 6.60 \mathrm{x}$ $0.36=\$ 2.376$ and profits after tax are $\$ 6.60-\$ 2.376=\$ 4.224$.

Assume owners of both institutions have a marginal personal tax rate $\left(t_{p}\right)$ of 20 per cent. If profits after tax are fully distributed as (franked) dividends, the owners will have a grossed-up dividend income of $\$ 6.60$ and a tax liability of $\$ 6.60 \times 0.2=\$ 1.32$. Since they have received tax credits of $\$ 2.376$ (the amount of company tax paid) they will be able to use the remaining $\$ 1.056$ of tax credits to offset other personal tax liabilities. Total tax paid arising from the institution's profit is thus $\$ 2.376-\$ 1.056=$ $\$ 1.32$. If the institution cannot distribute profits and associated franking credits, there is no use of those tax credits to offset other personal income tax liabilities of owners, and the total tax paid will be the amount of company tax paid, which is $\$ 2.376$.

This example demonstrates that, if the personal tax rate of the owners is less than the company tax rate, the total tax bill will be lower for the intermediation undertaken by the organisation able to distribute dividends. ${ }^{6}$ Thus, if credit union members are

Algebraically, this can be seen by noting that profits after company tax are $\mathrm{P}=(\mathrm{ra}-\mathrm{rdD} / \mathrm{A}) \mathrm{A}(1-\mathrm{tc})$
and that when these are paid out as franked dividends, the amount available to owners after personal tax
payments is $\mathrm{P}^{*}=(\mathrm{ra}-\mathrm{rd} \mathrm{D} / \mathrm{A}) \mathrm{A}(1-\mathrm{tp})$. The govemment's total tax take is thus $\mathrm{T}^{*}=(\mathrm{ra}-\mathrm{rdD} / \mathrm{A}) \mathrm{Atp}$. If 
predominantly from lower-income groups (and so have marginal personal tax rates below the company tax rate), the inability of credit unions to pay dividends leads to a wastage of franking credits and a competitive bias against such organisations relative to a joint stock company with an equivalent group of owners.

\section{Capital Requirements}

Since 1992, Australian credit unions have been subject to risk-weighted capital adequacy requirements equivalent to those imposed on banks under the Basle Accord. This has a number of consequences for credit unions.

Growth constraints. Capital adequacy requirements imply that growth can occur only if the capital base also expands. This creates a particular problem for cooperatives, since the only significant source of additional capital is through operating surpluses (Amounts contributed by new members as share capital are of nominal amount only - $\$ 2$ to $\$ 5$ each typically - and do not constitute 'permanent' capital since they can be withdrawn when leaving the cooperative.) Rapid growth requires large surpluses, but to achieve large surpluses deposit rates must be set relatively low and loan rates relatively high — settings which are not conducive to attracting business and growing rapidly. In contrast, other financial institutions can grow rapidly if opportunities exist by attracting new capital from equity investors.

Complications are also created for coping with growth opportunities. For example, a cooperative with sudden natural growth opportunities will need to achieve a higher return on investment to meet capital adequacy requirements. If, for example, growth opportunities exist because of growth in the common bond membership, existing members will bear the major burden (in the form of higher loan rates and lower deposit rates) of the higher return on investment required to permit the extension of services to new members.

the profits cannot be distributed, the amount available to owners (as communal wealth of retained earnings $)$ is $P=(\mathrm{ra}-\mathrm{rdD} / \mathrm{A}) \Lambda(1-\mathrm{tc})$ and the government's total tax take is $\mathrm{T}=(\mathrm{ra}-\mathrm{rd} \mathrm{D} / \mathrm{A}) \mathrm{Atc}$. 7

In fact, capital adequacy requirements imply a limit to the natural growth rate of credit cooperatives. Some idea of the implied limit on credit union growth rates can be gained from some simple calculations. The maximum growth rate for credit unions relying on internally generated capital to maintain a constant capital ratio is given by the ratio of profits to equity capital (known as the return on investment, ROI). An ROI of 12.5 per cent a year means that retained profits, and the resulting increase in equity capital, will amount to 12.5 per cent a year. If total assets were to grow faster than this, the capital ratio would fall. In practice, the maximum growth rate compatible with a constant capital ratio will depend on both the size of that capital ratio and the return on assets generated by the institution. For example, ROI can be rewritten as ROI - ROA (A/E) where ROA is return on total assets, $\mathrm{A}$ is total assets and $\mathrm{E}$ is equity. For credit unions ROA has typically averaged around 1 per cent a year. A capital requirement of 8 per cent is equivalent to a ratio of $\mathrm{A} / \mathrm{E}-12.5$ (assuming all assets have a risk weighting of one). Combining, we obtain an implied value for ROI of .125 or an implied growth rate of total assets of 12.5 per cent a year. While the average risk weighting of credit union assets is less than one in practice, maintenance of a riskweighted capital ratio of 10 per cent or more (as seems to be the tendency) means that this implied growth rate is probably not too far wide of the mark. 
The Wallis Inquiry suggestion (1997:358) that 'restrictions on the classes of debt and equity that may be issued by DTIs, particularly by mutual institutions, should, as far as possible, be removed', while aimed at facilitating depositor protection, would increase the ability of credit unions to cope with such growth opportunities by raising external capital. An additional advantage of any such external fund raisings would lie in the introduction of a new class of stakeholders with strong incentives to monitor the management of the credit union.

The cost of credit union capital. 'Permanent' capital can be accumulated by credit unions only through retained surpluses from operaling activities. Since members' transactions with the cooperative generate the operating profit, they bear the cost of creating such capital; but they receive ill-defined benefits.

Every dollar of surplus generated and retained by the credit union is a dollar 'lost' to individual members. They do gain something: the possibility that reserves may absorb losses while they remain members, and thus provide protection for their deposits. But the inability of members to access their contributions to the cooperative's capital if they leave the cooperative means that this benefit is bound to be worth less than the dollar given up. In effect, the cooperative is 'taxing' its current members, and the benefits will flow primarily to future members, who gain from the security implied by large accumulated surpluses generated before they joined.

One might argue that, luckily for credit union managers, most members do not recognise the extent of this tax. However, the cost is implicit in interest-rate spreads. Members will react to excessive taxation by taking their loan and deposit business elsewhere, so hastening the demise of credit unions. They might, if informed, support such a tax as part of their contribution to communal goals; but they should at least be made aware of the cost to them (and of general benefits to current and future members) of the credit union acquiring capital.

Wealth, protection and control. One consequence of capital adequacy requirements, then, is that credit unions are amassing a significant stock of wealth to which there are ill-defined ownership rights. This raises several important issues.

First, to whom does this wealth belong if the credit union is wound up or converted into an alternative form? The recent conversion of several building societies from mutual to transferable-share form has resulted in large transfers of members' wealth to those lucky enough to receive share allocations. Davis (1996) argues that the existence of accumulated surplus creates a potential conflict between older and younger members, since the former have incentives to vote for the wind-up or conversion of the cooperative in order to privatise the communal wealth, even if such actions destroy valuable social capital in the form of the cooperative enterprise. The argument is that the present value to older members of future benefits from credit union membership is lower than their potential share of communal wealth if the credit cooperative is wound up or converted to joint-stock form. But the one-person-onevote rule common to credit unions works to inhibit such an outcome and so helps them survive. 
Second, if capital adequacy regulation has the intended effect of making depositors less concerned about deposit safety, we can expect them to take even less interest in credit union affairs than they do currently. If concerned depositors do not monitor management; if the common bonds which may have kept managers' interests close to those of members are eroded; and if there is no share market discipline, what mechanisms will act to prompt efficient management? Probably none, unless the supervisory authority plays a role, or unless credit unions adapt in some way to improve oversight of management by members.

\section{Weakening the Common Bonds}

Common bonds have become restrictions on eligibility for credit union membership in name only, as criteria for membership have been relaxed significantly. This has a number of consequences for any natural advantages that credit unions may enjoy.

Credit unions with 'tight' common bonds may have significant information advantages. Ex ante risk assessment may be improved because of the greater information available about member characteristics. In addition, ex post monitoring of borrowers is enhanced because of the communal linkages. Finally, social arrangements within the common bond provide a form of 'bonding' mechanisms among borrowers, who will therefore be less willing to default on obligations to the cooperative and thus their fellow members.

Because of the relatively transparent nature of the organisation, providers of funds to credit cooperatives with tight common bonds can observe their funds being used in the form of loans to members of the communal group. But, as common bonds expand, the lack of correlation between fund providers and fund users reduces this advantage.

Credit unions are able to provide many services requiring large-scale activities because of cooperation between individual credit unions or as members of industry associations. Cooperation is aided by the absence of competition between credit unions whose common bonds do not overlap. But as common bonds are widened, and individuals become potential members of many credit unions, competition for business between credit unions may inhibit their willingness to cooperate.

\section{Technology and Financial Innovation}

The information revolution has had many effects on the financial services industry in the form of new products and new techniques. But it is also affecting some of the basic sources of the intellectual capital of financial institutions such as cooperatives.

First, financial intermediaries develop relationships with customers, who thereby gain valuable knowledge capital and so can make more informed lending decisions. But modem technology has made information data bases accessible by subscribers, so that a prior relationship with a potential borrower may now confer less information advantage. If the Wallis Inquiry recommendation 99 that 'a working party on positive credit reporting should be established' (1997:520) leads to the establishment of such positive credit databases, knowledge capital of individual institutions about credit risks 
may become even less of an advantage.

Second, credit unions initially emerged as providers of small personal loans. Such loans involve high transactions and administration costs. Credit cards involving revolving credit facilities have eaten into this market and prompted credit unions to develop other loan products such as housing loans. However, the development of the mortgage securitisation market has further increased competition in this area.

Third, although not directly a result of technology, competition in financial services has led to an unbundling of financial products and a reduction in the extent of cross-subsidisation possible across customers and products. Credit unions have for many years engaged in cross-subsidisation - arguably, that is part of their raison d'être - as different members received benefits at different times but their long-term commitment to the credit union smoothed out the cross-subsidies over time. But as common bonds weaken; as customers become more mobile; and as competitors remove cross-subsidies, credit unions are exposed to 'cherry picking' by individuals who utilise the subsidised services only. Many observers have expressed concerns that credit unions are subject to a form of adverse selection as they attract 'expensive' customers shunned by the banks. This could result in a possible downgrading of the average quality of customer business and ultimately of services to all members, in turn prompting exit by more 'valuable' customers.

\section{Asset Portfolio Restrictions}

Common bonds restrict credit unions to particular individuals whose needs may be quite similar because of geographical, industrial or community factors. This makes possible cycles in liquidity due to demographic characteristics, as a result of which credit unions may be unable to meet the 'Prime Objects' requirement (namely, that loans to members must exceed a specified percentage, currently 60 , of total assets) set down in Australian Financial Institutions Commission (AFIC) legislation.

That legislation should be amended, since it takes a product-based rather than a functional view of the role of the credit union. The economic functions of credit unions include originating and funding loans; but there is no reason why these functions need to be performed jointly, as implied by the legislation. Likewise, credit unions provide savings facilities; but there is no reason why they should be required to invest in a particular set of assets.

\section{Regulatory Biases against Cooperatives}

Regulation is biased against cooperatives in three main ways. First, credit unions in Australia are widely thought to enjoy a lower level of protection than banks and other institutions. Whereas the public assumes that bank depositors' funds are guaranteed, despite statements to the contrary by the Reserve Bank of Australia (RBA), that misconception does not apply to credit unions.

The Wallis Inquiry recommendation 36 that 'a single DTI licensing regime should be introduced' (1997:324) and the suggestion associated with recommendation 54 that 'the depositor preference mechanism that applied to banks should ... be ex- 
tended to all regulated DTIs' (1997:358) could serve to place credit unions on a similar basis to other institutions in this regard. However, the suggested retention of a distinction between 'banks' and other DTIs leaves open the possibility that public perceptions of a difference in degree of protection may remain. While the Wallis Inquiry recommendations permit mutual organisations to become banks, the minimum capital requirement of $\$ 50 \mathrm{~m}$ makes that an option only for very large credit unions.

A second possible source of bias arises from the fact that credit unions are supervised by AFIC and contribute to the costs of that supervisory body. Banks are supervised by the RBA and make no explicit contribution to the costs of that institution. They do, however, hold non-callable deposits with the RBA, which attract an interest rate five percentage points below the market rate of interest; this 'tax' on banks can be viewed as a form of contribution to supervisory costs. Bank representatives also claim that the Prime Asset Ratio requirement, requiring them to invest a proportion of assets in Commonwealth government debt, is also a 'tax', even though those assets are purchased at market rates of return, and the investment in low-risk assets would in the absence of de facto guarantees) tend to lower the cost of capital for the banks.

The Wallis Inquiry recommendations to the effect that regulatory agencies should charge explicitly for the cost of their services rather than through implicit taxes such as sub-market interest rates on non-callable deposits would, if enacted, remove any existing imbalances.

Third, current AFIC legislation enshrines a 'Catch 22' barrier to the creation of new credit unions. Minimum capital requirements impose a minimum ratio of capital to risk-weighted assets, where the eligible capital can take the form only of, essentially, accumulated profits: an impossible requirement for newly established credit unions to meet. Ways around this barrier have been found, using sponsorship by already established credit unions. But the rationale for such a barrier must be questioned, and the Wallis Inquiry notes (1997:343) that, while minimum capital requirements on new entrants should be retained, a flexible and facilitative approach should be adopted by its proposed regulator the Australian Prudential Regulation Commission.

\section{Sources of Optimism for Cooperatives}

Yet although the credit unions' natural advantages have declined, other factors are working in the opposite direction.

One development of significance has been the Wallis Inquiry into the Australian financial system. As noted above, the recommendations of that inquiry hold promise for a levelling of the playing field in regard to public perceptions of safety of banks relative to other depository institutions, while the proposed rationalisation of prudential supervision could be expected to remove any regulatory imbalances. Recommendations advocating: direct participation in the payments system, the right to offer retirement savings accounts, the ability of mutual organisations to hold all classes of licences, and the possibility of access to exchange settlement accounts at the Reserve Bank, are among those holding out potential benefits for credit unions and enhancing survival.

Financial innovation also holds out the prospect of offsetting some of the disad- 
vantages of credit unions, at least in principle. Securitisation makes it possible for institutions with a shortage of equity capital to provide loan origination and monitoring services, and thus to service a growing membership base demanding loans. It does not help, however, if the growth is occurring on the deposit side - although investing depositors' funds in liquid and low-risk-weighted assets can allow this demand to be met, provided the (in my view inappropriate) Prime Objects ratio requirement is not breached. New instruments such as credit derivatives also provide the opportunity for diversification of credit risk, allowing credit unions based in particular industries or geographical areas to reduce overall credit risk. In practice, the use of such new financial products is limited by the inability of management of small credit unions to understand them fully and by cost impediments to the creation of small-scale credit derivatives.

Electronic commerce also raises interesting possibilities for the future of credit unions. Provided access to the electronic networks is available, the ability of customers to access funds at locations remote from physical premises of the credit union reduces one of the potential disadvantages of small credit unions. This is an area in which the role of the Australian Competition and Consumer Commission is crucial in ensuring fairly priced access to common-use facilities such as the electronic network.

\section{Clarifying Ownership Rights}

Perhaps the greatest problem for credit unions is the inherent incompatibility of the accumulation of capital reserves with a cooperative institution. It seems unlikely that governments will back away from depositor protection based on capital requirements; and this raises the question of the suitability of the current organisational form of credit unions to the modern financial prudential-regulation framework. Continued growth of accumulated reserves may simply serve to increase the incentives for exploitative behaviour aimed at converting communal wealth into private wealth. Capital requirements, aimed at protecting depositors in credit unions, may paradoxically lead to the demise of credit unions.

It therefore seems appropriate for credit unions to endeavour to find a new institutional form consistent with the new environment. In some respects, the solution is straightforward. Since the main problem revolves around the lack of ownership rights attaching to accumulated surpluses, a form which provides such rights would make sense. For example, all members could be credited with a 'share account' to which their share of retained earnings for that year is credited. On leaving the credit union, members would, after some qualifying period, be able to withdraw the funds in the share account. Under such an arrangement, the credit cooperative would face fewer constraints in accumulating capital, would have a relatively stable (although not permanent) capital base, and would retain the cooperative principle as the basis of its activities. Another option is to issue an alternative form of 'semi-permanent' capital (perhaps some form of redeemable preference shares) which qualifies as 'second tier' capital for regulatory purposes, provides a means for distributing franking credits, and carries limited voting rights, thereby maintaining the cooperative nature of the institution. Naturally, providers of such capital would have strong incentives to monitor 
management actions, thus enhancing the efficiency and safety of credit unions. Already, several Australian credit unions have raised second-tier capital of such a form.

It seems likely that further developments of this type will occur as the organisational form of credit unions continues to evolve to cope with the changing nature of the financial system. The Wallis Inquiry recommendations have widened the options for credit unions. However, by reducing some institutional impediments to competition (such as allowing for the possibility of commercial firms, like retailers and communications firms, to establish deposit-taking subsidiaries) they may have made the competitive pressures on credit unions even more severe. If that is so, a continuing decline in the number of credit unions could occur, as boards and managers of small credit unions decide that continued separate existence in such an environment is too hard and elect for the merger option. This could lead to a small number of large credit unions, adhering to the mutuality principal but losing most of the benefits which originally gave rise to the case for that organisational form.

\section{References}

Crapp, H. \& M. Skully (1985), Credit Unions for Australians, Allen \& Unwin, Sydney.

Davis, K. (1985), 'Thrift Institutions', Chapter 3 in M. Lewis \& R. Wallace (eds), Australia's Financial Institutions and Markets, Longman Cheshirc, Melbourne.

- (1996), 'Incentive Compatible Govennance in Coopcrative Financial Institutions', Working Paper, Department of Accounting and Finance, University of Melbourne

Deshmukh, S., S. Grecnbaum \& A. Thakor (1982), 'Capital Accumulation and Deposit Pricing in Mutual Financial Institutions', Journal of Financial and Quantitative Analysis 17(5): 705-25.

Kane, E. \& R. Hendershott (1994), The Fedcral Deposit Insurance Fund That Didn't Bark in the Night, National Burcau of Economic Research, Cambridgc, Mass. (NBER Working Paper No. 4648).

Mayers, D. \& C. Smith Jr (1986), Ownership Structure and Control: The Mutualisation of Stock Life Insurance Companies, Joumal of Financial Economics 16: 73-98.

Miles, D. (1994), 'Economic Issucs in the Regulation of Mutual Financial Services Firms: The Case of U.K. Building Societies', The Manchester School 62(3): 227-50.

Patin, R. Jr \& D. McNeil (1991), 'Member Group Orientation of Credit Unions and Total Member Benefits', Review of Social Economy 49(1): 39-61.

Rasmusen, E. (1988), 'Mutual Banks and Stock Banks', Jounal of Law and Economics 31: 395-421.

Smith, D., T. Cargill \& R. Meyer (1981), 'An Economic Theory of a Credit Union', Journal of Finance $36(2): 519-28$.

Wallis Inquiry (1997), Financial System Inquiry Final Report, AGPS, Canberra.

This is an edited version of a paper presented at the Workshop on Research in Cooperative Societies, conducted by the Centre for Australian Financial Institutions at the University of Southern Queensland, 16 December 1996. 